\title{
Network Analysis on Increasing Brazilian Migrants in Hamamatsu,
} Japan

\author{
Crispin Magige Ryakitimbo ${ }^{1} \&$ Babul Hossain ${ }^{1}$ \\ ${ }^{1}$ Department of Sociology, School of Public Administration Hohai University, Nanjing, China \\ Correspondence: Crispin Magige Ryakitimbo, Department of Sociology, School of Public Administration Hohai \\ University, Nanjing, China.
}

Received: October 10, 2019

Accepted: November 6, 2019 Online Published: November 13, 2019

doi:10.20849/ajsss.v4i4.670

URL: https://doi.org/10.20849/ajsss.v4i4.670

\begin{abstract}
Migration is a movement of people from one region to another, at an international level the migration takes place from one country to another. Japan has a history as a country that is closed, does not want to open up with other countries. But as a result of the economic downturn, the Japanese government wants to withdraw Nikkeijin (a foreign citizen who is still of Japanese descent) to return to Japan and work in Japan. Brazilian Nikkeijin has a history with Japan where the early history of the Japanese population immigrated more to Japan, led by Kasato Maru. Hamamatsu City, Japan, is Japan's most industrialized city entered by the Brazilian Nikkeijin. There is a network influenced by an increase in migrants in Hamamatsu, Japan. This study analyzes the network in increasing Brazilian migrants in Hamamatsu, Japan in 2000-2006 using network theory proposed by Doughlas S. Massey.
\end{abstract}

Keywords: international migration, Brazilian Nikkeijin, Japan, network theory

\section{Background}

Migration has emerged as an international phenomenon. Migration is a movement of people from one city to another and settled in a border area in a country. Broadly speaking, migration can be divided into two namely national and international migrations. National migration is migration that occurs within a country. Whereas international migration is migration between countries, in the case of a permanent resident of a population and migration outside the borders of the country. International migration is easier in the era of globalization as it is now in, where borders between countries are more transparent, means of transportation and communication can be used more easily. For this reason, migration is a very important phenomenon, given that people can easily move outside a country. The migration factor to get a better life causes the movement of people from one country to another with the aim of getting a job. This creates what is meant by overseas migrant workers. The existence of international migrant worker migration is able to reduce global inequality, not only in relation to contributing a large amount of remittance to the country of origin, but also contributing to reducing inequality in other aspects such as gender, race, and class (Soetjipto, 2013).

One phenomenon that is of interest is the international migration relationship between Japan and Brazil which has a history of strong relations where Brazil is the main destination of Japanese migrant workers. On June 18, 1908, the first Japanese group of ships, led by Kasato Maru, left the port of Kobe in April and arrived at the port of Santos, $60 \mathrm{~km}$ south of Sao Paulo (Nakamura, 2008). After the Meiji restoration, restrictions on going abroad began to be removed, so that the Japanese population could freely travel abroad or move out of the country to get a better life. Japanese who migrate to a country are called Nikkeijin, the term "Nikkei" or "Nikkeijin" refers to Japanese who have migrated permanently until their second, third, fourth generation offspring, renounce their nationality. One of them is Nikkei Brazilia or commonly referred to as Japanese Brazilia, a citizen of Brazil, a descendant of the Japanese State who used to be Japanese immigrants living in Brazil.

In the 1980s, the Brazilian economy began to decline. In addition, the social and political conditions of the country of Brazil also experienced a crisis. One effort that is considered to be profitable and is seen as able to fulfill their daily needs is to immigrate to other countries. This made Nikkeijin decide to move to Japan in large numbers and work in Japan as a "dekasseguiser" or as a part-time worker (Calazans, 2009). On the other hand, Japan is facing the problem of aging population, which is a shift in the age distribution (age structure) of the population towards older age (Hidayati, 2014). In Japan, aging population is characterized by the impact of 
slowing population growth, a considerable number of elderly people, the occurrence of shrinkage of labor due to low birth rates and minimal immigration, plus the younger population does not want to do work in fields that are considered difficult, cultured and dirty or known as the term 3K (kutsui, kiken, kitanai).

In the 1990s, the number of migrants from Brazil increased rapidly. This is because the government provides visa facilities for Nikkeijin to enter Japan, so the number of migrant workers, especially from Brazil, is growing rapidly and filling the middle employment sector. In every body, the Nikkeijin population going to Japan continues to increase. Starting in 1990 a total of $5 \%$ of Brazilian migrants entered, and continued to increase, as in 1992 which reached 10\% of Nikkeijin entering Japan. The Nikkeijin population continued to increase until in 2006 it reached 13\% of the total Brazilian migrants entering Japan. Cities such as Toyota (Aichi Prefecture), Hamamatsu (Shizuoka Prefecture), and Oizumi Ohta (gunma Prefecture) are the center of the industrial city in the field of cars and electronics. Brazilian Nikkeijin concentrates more there, where the work is more on $3 \mathrm{~K}$ work (kiken, kitanai, kutsui), which is dangerous, dirty, and demanding. In the city, visitors can easily find shops and equipment from Brazilian products and offer services in Portuguese (Koji, 2008). The city of Hamamatsu, an industrial center located in Tokyo, is home to the most Brazilian migrants in Japan. In the city, many buildings and shops are owned by Brazilian.

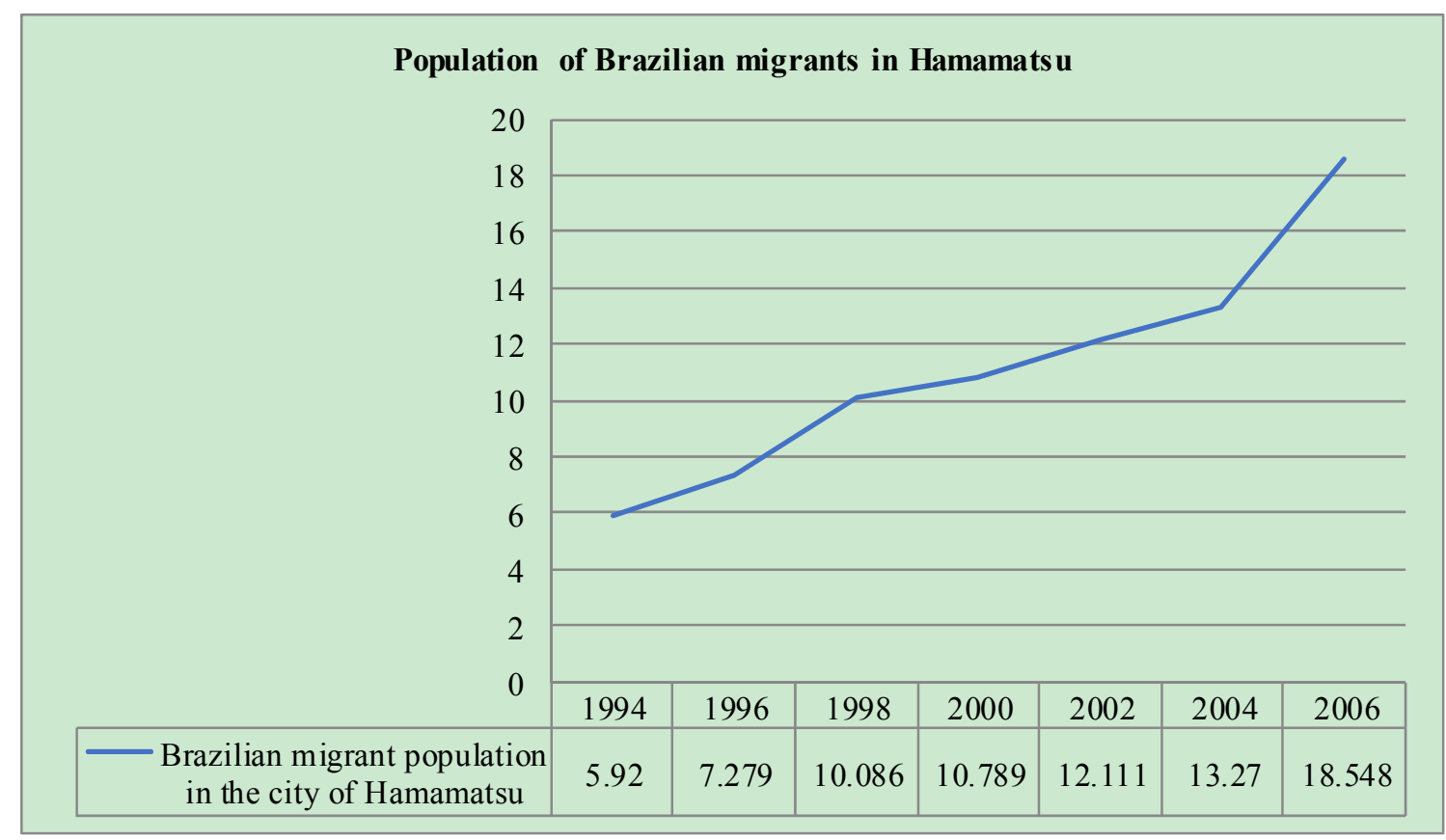

Figure 1. Population of Brazilian migrants in Hamamatsu

Source: Ministry of Justice

The figure above shows the population of Brazilian migrants in the city of Hamamatsu, beginning in 1994 at 5,920. The population continues to increase where in 2000 the population of Brazilian migrants reached 10.789 and continues to increase every year. Proven that the city of Hamamatsu which is the largest industrial city in Japan can encourage Brazilians to enter Japan, work and establish the needs of the people of Brazil in Japan. However, with the growing population of Brazilian migrants in Hamamatsu, there is no balance between socialization between Brazilian migrants and Japanese residents there, such as in terms of culture and education. Because of the culture that is owned by Brazilians who are more open, although they inherited Japanese culture from their ancestors, the culture began to fade. While the Japanese character is more closed making life together is not easy.

The focus in this study of this phenomenon is the role of the network towards the increase of Brazilian migrants in Japan in 2000-2006, especially in the city of Hamamatsu which is the center of Japanese industry and has the largest number of Brazilian migrant populations compared to other cities in Japan. Brazil's population in 
Hamamatsu continues to increase from year to year. On the other hand, a significant increase in the Japanese population with the presence of Brazilian migrants is not matched by social, cultural and educational problems. Because the Brazilian character is very different from the Japanese where the Brazilian character is more open and straightforward, while the Japanese are closed and individual, which makes it difficult to live together. In addition, although Nikkeijin still has Japanese blood, it does not fully inherit Japanese culture and language.

\section{Literature Review}

\subsection{Network Theory (Douglas S. Massey)}

Migration is defined as the movement of population with a permanent or semi-permanent nature in a place through the state boundaries of a country. Migration cannot be separated from the entry of population into a destination area and the movement of population out of a place of origin. Migration develops from year to year as the area of immigration expands. In the past, migration only occurs to countries like the United States, Canada, and Australia, but now it also occurs in countries in Europe and Japan or countries with developed economies are also destination countries for migration. Japan is a destination for immigration because of the declining rate of population growth and aging population growth requires labor intake from Asia and South America. Each individual migrates will change the social context that adds to the desire of the individual to migrate again. With the increasing participation of migrants in various regions and the effect on multiethnicity in destination countries or advanced industrial countries, it is necessary to explain in theory and explain why migrants do migrate again.

The approach emphasizes systems that can combine various levels of analysis and theoretical approaches. When linked to migration, migrant networks are a series of interpersonal relationships that connect between migrants, non-migrants, and who have migrated in a friendship or family network and the similarity of origin of the network which can be interpreted as a social capital formed in migration that facilitates migration because it reduces the costs and risks of migration with the availability of information (King, 2012). Personal and social networks are relational relationships in which the network will cause migration over time, and resolve theoretical debates between the causes of migration, the sustainability of migration, and its adjustment to time and place.

In this research, a description of international migration, the use of network theory belongs to Doughles S. Massey, Joaquin Arango, Graeme Hugo, Ali Kouaouci. Adela Pellegrino, J. Edward Tailor. Massey's network theory describes interpersonal relationships in the form of family, friendship and fellow community that connects migrants who migrate and non-migrants both from the origin and destination. When an initial migration takes place, migration will become more common in society, and more people will follow the flow of the migration. The migrant network is defined as a relationship between migrants and non-migrants binding with the aim of facilitating the entry, adjustment, and employment of the destination (Massey, 1994). The existence of a migrant network for someone with migratory experience is helpful because it is an important resource that can be utilized to facilitate one's movement to migrate, where relationships within one person change relationships that can be used for anyone to facilitate migration. Which can explain how migrant networks operate, is social capital. Social capital is assumed that actors migrate to maximize their investment returns in the form of human capital that does so, as well as utilize human capital in their interpersonal networks (Spittel, 1998). By using social capital, then the costs and risks associated with migration are reduced, namely access to safe transportation, housing, work, and social interaction. With the existence of social capital, it is possible for increased migration.

\section{Declining costs}

Declining cost is a potential cost of migration that encourages people to migrate and creates a system that further magnifies the urge to migrate. Migrants who make the move for the first time spend quite a lot of money in the absence of social networks, especially if they do not have the required documents. But for family and friends, migration will be cheaper with friendship and family relationships or migrants connected with their home regions (Massey, 1994). Kinship networks are an important basis in migrant social organizations, because they can provide the safest connections. On the other hand, migrants also establish social relations of friendship and family with non-migrants at the destination to get access to job openings. For this reason, migration will recur because every migration occurs forming a social structure that supports the existence of this phenomenon. Each new migration that occurs will reduce costs for family and friends, thereby encouraging migration and expanding the network of relationships outside and reduce costs for others who want to migrate. Because each new entrant will create a new social bond to the migration destination and the migrant network tends to reduce the direct costs of migration, information and search costs as well as psychological opportunities and costs of migration.

Each new migrant, can reduce the cost of the next migration for a group of friends and relatives, and some people who will migrate, and subsequently expand ties abroad, which in turn reduces the cost for a new group of 
people and influences the cycle to migrate continuously. As said by Massey, with the network, it can provide access to safe transportation, housing, work, and social interaction. It also reduces travel costs because it will get safer and cheaper travel routes. So the cost of migrating will tend to decrease. In addition, it can reduce the cost of living of new migrants by providing financial assistance when new migrants arrive at their destination. Migrant networks increase the occurrence of migration because it reduces the costs of migrating including costs in traveling migration, money spent on getting information and finding new jobs, opportunity costs incurred while searching for work, psychological losses caused by environmental placement which is different from the workplace.

\section{Declining risk}

The definition of declining risk is where migration becomes an attractive strategy to carry out risk diversification, is easily accessible or the risk loss is increasingly displaced, and becomes a reliable and guaranteed income. Besides reducing costs, the network also makes international migration very attractive as a strategy for risk diversification. In addition, the existence of related policies can reduce risk by providing easy access to migration to the destination country. When the migrant network develops well, it will facilitate access to overseas work by community members so that it can be a safe and guaranteed source of income. With the new migration that expands this network of migration links, it will reduce the risks and costs that must be borne, making it attractive for people to migrate. According to social networks, migration is a risk of diversification with other income coming from outside, so that it is not affected by risks such as the occurrence of a recession in the country or get additional income (Palloni, 2001). Thus, independent network growth occurs through progressive reduction in risk because each new migrant expands the network and reduces risk for all people who ultimately make it almost risk free and without cost to diversify the allocation of household labor through emigration (Massey, 1994).

This dynamic theory accepts the view of international migration as an individual process or household decision, later building a system which changes the decisions that increasingly encourage the phenomenon of international immigration migration. The conceptualization of immigration as a self-sustaining process has different implications from those who normally study migration, namely:

a. Once this international migration has begun it tends to expand its connections to a wide spread of people who want to migrate and can do so without difficulty. International migration will develop until the network of relationships is large enough to make it easier for people to migrate and eventually this migration will decrease.

b. The size of the migration flow is not determined by wages or given because ultimately it will be diverted by the reduced costs and risks of migration with the development of the migrant relations network. Because any effect has prevented the progressive migration originating from migrant networks.

c. International migration becomes institutionalized through the formation and development of a network of relations which is increasingly detached from the initial causes of migration both structurally and individually.

d. The more developed the network of relationships and the smaller the risk of costs, the smaller the choice of socioeconomic factors, but rather the community. Because with the community can help migrants to arrange financing and avoid spending costs that are not appropriate.

e. The government has difficulty controlling this migration with a variety of policies to overcome this because of the relationship that is formed outside what can be controlled by the government.

f. But it can be done with policies that encourage reunification between migrants and their families in their home countries, working in cross-purposes with controlling the flow of migration because the network of relationships provides convenience for entry based on family relations.

\section{Research Methods}

This type of research is a descriptive study that will describe and explain the network analysis in increasing Brazilian migrants in Hamamatsu Japan in 2000-2006. The type of data used in compiling this research is secondary data type. Secondary data is data from the second source. The data can be derived from documents such as books, journals, newspapers, magazines. Data is taken in the 2003-2015. This research uses a literature study method which is conducted on the results of a study of how many relevant library materials such as a scientific journal, the official website of the agency to the electronic mass media. The data collected is then analyzed and finally conclusions are made. The data used is secondary to the use of literature study. 


\subsection{History of Nikkeijin Brazil in Japan}

The term 'Nikkei' or 'Nikkeijin' refers to Japanese people who have moved out permanently until their second, third, fourth generation off spring, renounce their nationality (Kojima, 2017). One of them is the Brazilian Nikkei or commonly referred to as Japanese Brazilian, a Brazilian citizen of Japanese descent who was a former Japanese immigrant living in Brazil (Tsuda, 2008). The history of the existence of Japanese Brazilian began in 1908. The first immigrants in Japan to come to Brazil, hundreds of farmers migrated to South America in order to gain good fortune in the State of Brazil. On June 18, 1908, the first Japanese group ship, Kasato Maru, left the port of Kobe in April and arrived at the port of Santos, $60 \mathrm{~km}$ south of Sao Paulo. At the end of 1908, Japanese citizens massively moved to other countries to get a better fate and the State of Brazil was one of the countries to be addressed. By Japanese citizens, around 190,000 Japanese moved to Brazil between 1908 and 1941, when emigration was halted due to poor diplomatic relations between Japan and Brazil during World War II. But in the early 1950s migration from Japan to America returned and in the following decade thousands of Japanese citizens plotted their fortunes in Brazil. One of the reasons many Japanese migrate abroad, including to Brazil, is because the government promoted emigration as a national policy until the end of 1960, emigration was believed to be a problem solver of 'overpopulation' and poverty in rural areas (Nakamura, 2008). With the emigration or migration, it is hoped that they will get income for their families. Movements made by Japanese immigrants spread to various countries, their main destinations actually to the United States and Australia. However, both countries have sentiments towards Japan (anti-Japanese) because of racism and fear of losing their jobs. So Japan returned to South America, when Brazil needed cheap labor for coffee plantations after Italy stopped sending their farmers in 1902 (Santos \& Agusto, 2002). After the era of the world war, Japan promoted emigration to the South American region to reduce the problem of food shortages and overpopulation after Japan returned to war.

In the 1980s, the Brazilian economy began to decline. The economic, social, and political state of Brazil is experiencing a crisis. As a result of the decline in estate crop yields, wages given to coffee plantation workers are also not comparable to working hours as farmers (Vogt, 2012). This makes the population of the State of Brazil immigrate to other countries. Besides and that, more or less "Japanese-descent Brazilians" decided to work in Japan as "dekasseguisers" or as part-time workers. Along with the crisis in Brazil, Japan is faced with labor shortages, demographic changes where births are declining and the majority population is older (Vogt, 2008). Slower population growth, the number of elderly people is not small, and young Japanese residents who do not wish to do work in the $3 \mathrm{~K}$ field: Kutsui, Kiken, Kitanai (difficult, dangerous, dirty), making Japan decide to take workers from outside. The decline affected the manufacturing sector and low service wages. This influence made the Japanese government oppose the liberalization of foreign immigration policies and offered stable jobs to newcomers. The first recruiters were first generation migrants who worked in Japan and were asked to bring other Nikkeijin people to Japan. They returned to Brazil and began hiring Nikkeijin. The first recruitment agency office was opened by a migrant who returned in 1984. Another migrant who re-opened the office in 1986 as a branch of a Yokohama-based labor contractor where migrants used to work (Kingsberg, 2015). The latter formed a recruitment network from the Amazon to Argentina and Paraguay. The network of recruitment agents soon spread throughout the Japanese community in South America. In addition, recruiters began lending the necessary fees to Japan in 1887. This loan system quickly became a standard requirement for recruiting, which allowed even the poorest Nikkeijin people to immigrate (Sasaki, 2008).

The long-term review since 1993 has had a significant influence on Brazil's migration to Japan so it is not surprising that the number of Brazilian migrants has suddenly dropped, although part of it may reflect a shortage of labor reserves in Brazil. However, in fact, Brazil's population has continued to increase throughout the period, which can be explained by two factors:

\section{New demand for flexible labor}

After the economic boom, the labor market has changed. The Nikkeijin were hired as temporary workers, in lieu of migrants from outlying areas such as Tohuku and Kyushu. During the economic boom, it is expected to overcome labor force. However, on the contrary they were employed during periods of economic stagnation as a very flexible workforce.

\section{Geographical distribution of workplaces}

Shizuoka and Aichi Prefecture have saved most of the population of Brazil, the Kanto region (Kanagawa, Gunma lbaraki and Saitama) has been exceeded by the Chubu region next to Shizuoka and Aichi (Nagano, Gifu, and Mie). Many labor contractors in Shizuoka and Aichi find labor markets that can be exploited in semi-peripheral areas in the Chubu region. That is why the number of Nikkeijin continues to increase during the recession. 
In 1990 the Japanese government revised "The Immigration Control and Refuge Recognition Act" for the long term, renewing visas for non-citizen children as well as grandchildren descended from Japanese emigrants (Kashiwazaki \& Akaha, 2006). The government insisted on changing the state order intended to strengthen the culture and affective relations between the Japanese diaspora and the nation-state of Japan. The Japanese state amended "The Immigration Control Law" with the aim of accepting Japanese offspring abroad (second generation descendants or so-called Nisei-jin and Japanese third generation) called sansei-jin) and their spouses to come to Japan and work there for a long period of time, so many Japanese immigrants who lived in Brazil before, flocked back to Japan and worked there.

The number of second generation Brazilians has stagnated since 1992 while the number of third generation and non-generation Japanese pairs has increased. In the early 1990s the second generation Nikkeijin increased, and the majority was represented by third generation and non-Japanese couples. The hope of the Japanese government is that Japanese-Brazilian citizens who migrate in Japan can adjust to life in Japan. But in reality this transfer is not easy (Goto, 2006). Although Japanese-Brazilian citizens live in Japan, and their children born in Japan, the government still treats them as foreigners. As with Japanese citizens who had previously immigrated to Brazil for a long time, when they returned to Japan they were still treated as foreigners, not Japanese citizens. Many Brazilians whose descent and appearance are like Japanese and return to Japanese immigration policies regarding migrant workers. Policies and Government of the Japanese Government regarding migrant workers are quite clear. The revision of immigration laws in Japan has resulted in a dramatic increase in immigrants from Latin American countries such as Brazil, Argentina, Peru and Bolivia who want to work in Japan. Moreover, the wages earned in Japan are higher than in Latin America, which ultimately gives an interest in moving massively and working in Japan.

Japan is an archipelago located in East Asia. In terms of the economy of Japan occupies the 3rd position with an advanced economy in the world. GDP (value of goods and services produced in Japan in a year) Japan is the highest in the world, where famous Japanese brands have been able to expand its market outside Japan, such as Toyota, Sony, Fujifilm, and Panasonic. As for the manufacturing industry, it is also one of Japan's strengths that is recognized as a country, even though Japan is still poor in natural resources (Stelzig, 2008). The general pattern of the economy that is run by Japan is that they usually import raw materials from outside Japan which are then processed into finished goods which will then be sold in Japan and export.

Table 1. Number of foreign residents with a long-term residence Visa

\begin{tabular}{llllllll}
\hline Country & 2000 & 2001 & 2002 & 2003 & 2004 & Ratio (\%) & $\begin{array}{l}\text { Percentage } \\
\text { previous year }\end{array}$ \\
\hline Brazil & 137,649 & 142,082 & 139,826 & 140,551 & 144,407 & 57,6 & 2,7 \\
\hline China & 37,337 & 36,580 & 35,020 & 33,292 & 32,130 & 12,8 & 3,5 \\
\hline Philippines & 13,285 & 15,530 & 18,246 & 21,117 & 23,756 & 9,5 & 12,5 \\
\hline Peru & 21,369 & 22,047 & 21,538 & 21,045 & 20,779 & 8,3 & 1,3 \\
\hline Korea & 9,509 & 9,243 & 9,091 & 8,941 & 8,751 & 3,5 & 2,1 \\
\hline Other & 18,458 & 18,978 & 19,730 & 20,200 & 20,911 & 8,3 & 3,5 \\
\hline
\end{tabular}

Source: Japanese Ministry of Justice

The table above describes the number of foreign residents on a "long term residence" visa, showing foreigners from various countries living in Japan on long-term visas (Goto, 2006). It can be seen that Brazil's most populous country chooses to apply for a long-term residence visa in Japan compared to other countries which use fewer long-term visas. 
Table 2 Brazilian immigrants by city administration

\begin{tabular}{ll}
\hline City & Brazilian Immigrants Population \\
\hline Aichi & 40,873 \\
\hline Hamamatsu & 31,329 \\
\hline Nagano & 14,670 \\
\hline Kanagawa & 13,155 \\
\hline Gunna & 13,138 \\
\hline Mie & 12,903 \\
\hline Saitama & 11,532 \\
\hline Gifu & 11,202 \\
\hline
\end{tabular}

Source: Foreign Registration by Prefecture and by Nationality

From the table above, it shows that the population of Brazil in Japan is very large, especially in the cities of Aichi and Shizuoka. The response to Nikkeijin in the city of Hamamatsu (Shizioka) was different compared to the city of Aichi. It is the Hamamatsu City Association on the international Exchange that has played an important role, as well as other organizations such as The Chamber of Commerce and Industry and the Hamamatsu Junior Chamber of Commerce, which have dealt with issues regarding Nikkeijin.

The establishment of The Hamamatsu City Association for International Exchange is shown to build the city so that foreigners can live their life comfortably and as a means to promote the tourism sector. In 1993, the city of Hamamatsu confirmed The Department of Sociology of Toyo University to examine the Brazilian Nikkeijin situation, The Chamber of Commerce and Industry conducted a survey of companies employing foreigners, while The Hamamatsu Junior Chamber of Commerce investigated the issue of ongoing and future policies front of the cities which are concentrated with the highest foreign population. After further surveys and research, the results are obtained to gain an understanding of the company that employs foreigners and their conditions. The findings of these results become a reference for the Hamamatsu city government in paying attention to issues concerning foreigners as well as a reference in taking steps to understand the situation of foreigners who ultimately serve as input for policy making.

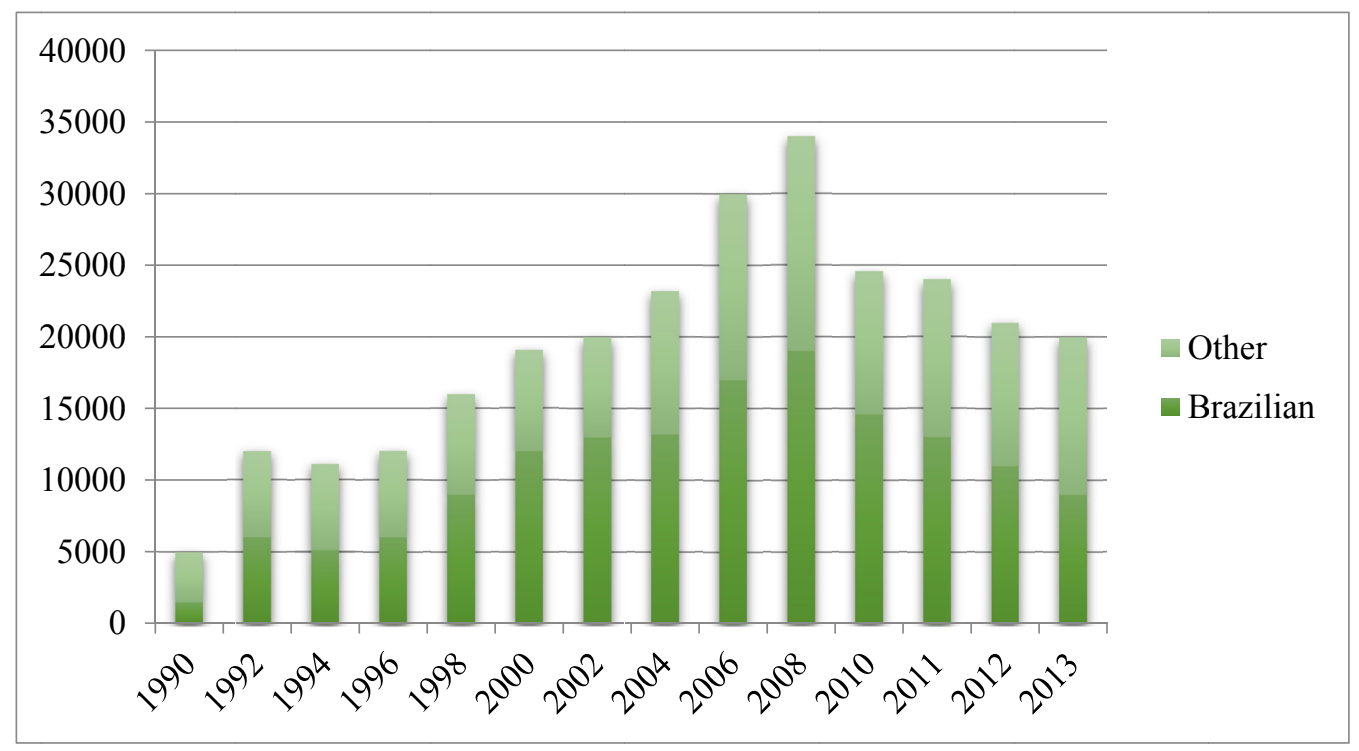

Figure 2. Number of foreign residents in Hamamatsu

Source: Hamamatsu International Affairs Division 
The graph above shows the number of foreign residents who registered their population (foreign residents) in the city of Hamamatsu. In the chart, there are foreign residents who come from Brazil and from other countries (others) and can be seen that each year has increased, such as from 2000 to 2006 the number increased to 15,000.

\section{Network Analysis in Increasing Number of Brazil Migrant in Hamamatsu Japan in 2000-2006}

\subsection{Social Network}

The problem of foreign migrant workers has received much attention in the Japanese media since the mid-1980s, during which Japan experienced a serious shortage of workers in the manufacturing and construction industries. Foreign population statistics show that in 2003, around 15.1\% of Brazilians in Japan lived in Shizioka. Increase in Brazilian migrants (Nikkeijin) Japan, cannot be separated and there is a social network (social network) between Brazilian migrants. Social worksheets become a foundation in the dissemination of information and is aids in certain networks that give influence in decision making and steps in migrating (Haug, 2008). With the existence of social networks can also provide migration facilities because it reduces the costs and risks of migration and the availability of information needed, so that it can provide direction for prospective migrants who will plan to migrate.

The beginning of the presence of Brazilian migrants (Nikkeijin) in Japan in 1908 and continued in 1990 which is increasing because of the provision of ease for migrant visas with population growth, and Japanese citizens who are reluctant to do $3 \mathrm{~K}$ work (kitsui, kitanai, kiken), which is difficult, dirty, and dangerous work (Higuichi, 2006). The factors above are the opportunity for the Nikkeijin to flock to Japan and look for opportunities to work. The families of Brazilian migrants who had previously settled in Japan also had a role in spreading information to their relatives or other Nikkeijin who were still in Brazil to move and work in Japan. It is proven in Graph 5.1 that describes the number of Brazilian migrant population who went to Japan, where the change which initially amounted to 56,429 in 1990, continued to increase until the population numbered to 254,394 in 2000.

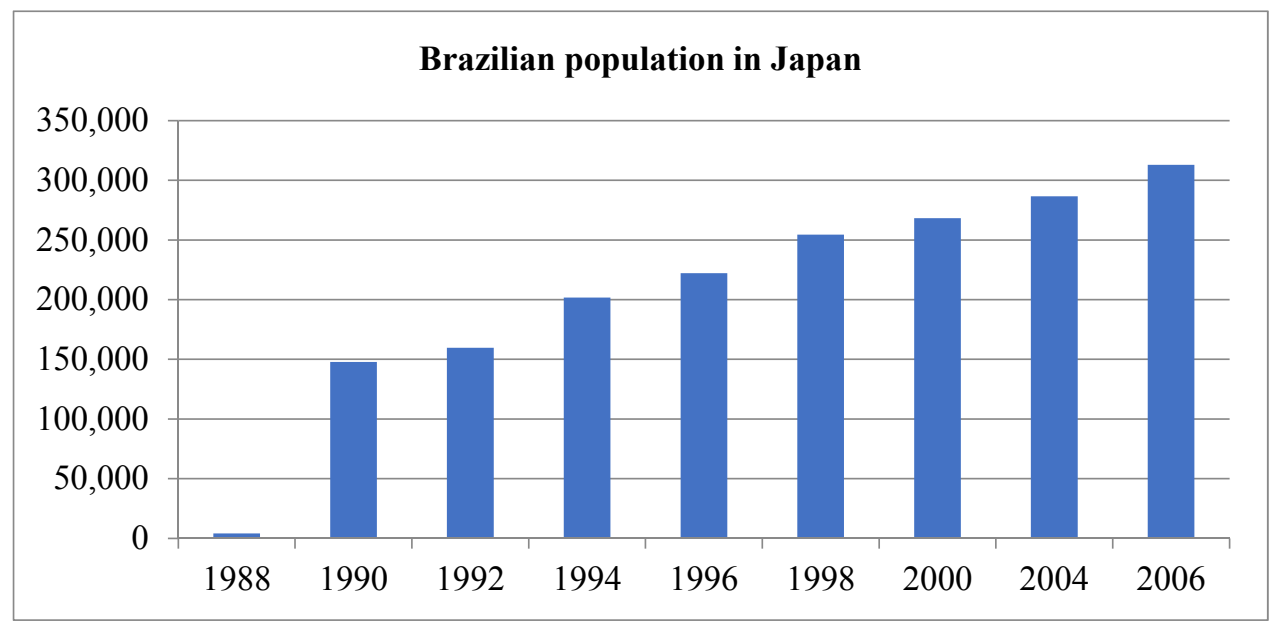

Figure 3. Number of Brazilian migrants to Japan

Source: Japan's Ministry of Justice

This high Nikkeijin population makes Brazil the 3rd largest population group in Japan and is referred to as a "newcomer" because they are descendants and Japanese so the government is given a long-term visa to stay longer in Japan. In accordance with the Brazilian population graph in Japan, the Nikkeijin are scattered in all areas of cities in Japan.

In an effort to strengthen relations between Japan and Brazil, the Japanese government held a symposium. On February 18, the Ministry of Foreign Affairs held a "Brazilian Community Symposium" which took place in Tokyo (Japan Institute of Labor Hall) which participated in the Symposium from the Japanese Ministry of Foreign Affairs, Ministry of Justice, Ministry of Health, Labor and Welfare, from local governments and NGOs, while on the Brazilian side, staff members from the Brazilian Embassy in Japan, as well as other academics from the Brazilian community in the Japan Symposium were held because the number of Brazilian migrants to Japan, especially Nikkeijin, has increased rapidly in recent years. The increasing population of Brazilian migrants in 
Japan, especially Japanese descendants in Brazil, Nikkeijin, makes Japan consider them to have become part of Japan's national dance. The Japanese government visited Brazil in an effort to strengthen relations between Japan and Brazil, and promote Japan in Brazil to work in Japan. The effort is that there are no boundaries between Japan and Nikkeijin, there is no racial homogeneity, because although Nikkeijin is of Japanese descent, their culture and race have mixed with Brazil. One of the efforts of the Japanese government in forming relations between Japan and Brazil was the arrival of the Japanese Prime Minister to Sao Paulo, Brazil in 2004.

Prime Minister Junichiro Koizumi visited Central and South America to attend the United Nations General Assembly on September 14, 2004. The first day Prime Minister Koizumi visited the site where the restoration work was carried out under an environmental improvement project funded through yen loans provided by Japan. Japanese Prime Minister's visit in order to strengthen Japan's relations with Brazil. In the afternoon, Prime Minister Koizumi visited the citrus orchards in Pradopolis, where in the early 20th century Japanese immigrants settled in the area. There Prime Minister Koizumi spoke with immigrants' grandchildren, Prime Minister Koizumi also met with former participants in the Japanese Teaching Exchange Program to invite young people from abroad to participate in international exchanges and foreign language education throughout Japan, as well as prominent Japanese representatives in Brazil.

On the second day of Prime Minister Koizumi's visit to Brazil. Prime Minister Taman Ibirapuera in Sao Paulo, where he offered flowers at "The Garden of Remembrance for the Pioneers" to commemorate the difficulties faced by Japanese immigrants. Prime Minister Koizumi gave a speech to about 1,200 people of Japanese descent in the Nikkeijin Cultural Society. Prime Minister Koizumi called for a deep vision. Partnership between Japan and Latin America to activate economic relations. In his vision, calling for increased cooperation in managing various issues in the international community. With regard to the exchange of people, Prime Minister Koizumi announced Japan's intention to invite for five years around 4000 young people in total, including exchange students, from Latin American countries.

On the third day of the Japanese prime minister's visit to Brazil, Prime Minister Koizumi held talks with Luiz Incio Lula da Silva, Resident of Brazil. From the results of the meeting, the two leaders agreed for Japan and Brazil to support each other to become permanent members of the UN Security Council, in cooperation with each other, to work to revive economic relations between Japan and Brazil.

Its spread is also most numerous in cities that are centered on industry. especially in the city of Hamamatsu. The city of Hamamatsu, where the industry is $300 \mathrm{~km}$ from Tokyo, is home to Brazilians and is the most inhabited by Brazilians, around 19,000 have settled there to settle in companies (Japan's BBC News, 2007). Hamamatsu is a very famous industrial area in Japan Famous brands were also born from the city, such as Yamaha Motor Co., Honda Motor Co., Suzuki Motor Co., and others. In the city of Hamamatsu, visitors can easily find shops and equipment. from products from Brazil and offer services in Portuguese. The city of Hamamatsu, an industrial center located in Tokyo, is home to the most Brazilian migrants in Japan. In the city, many buildings and shops are owned by Brazilian (Roth, 2002).

Brazilian migrants who work in Japan are called dekasseguisers, or what are called part-time workers (Calanz, 2009). Migrants who work in Japan in their daily lives experience considerable difficulties in the language used, especially their children, as well as very different cultures between Brazilian and Japanese cultures. To overcome this problem, many Nikkei organizations assist the dekasseguiser. In 2001, Hamamatsu Gilabal City Vision was formulated by the city of Hamamatsu as a guide for internationalization policies and promoting multilateral coexistence, namely discipline and cooperation for coexistence, as well as a part in promoting multilateral coexistence. Multilateral coexistence first appeared in the early 1990s, especially in Japan's Kansai region. The aim of multilateral coexistence is to dilute inter-cultural friction and improve social integration between foreigners and local residents, and to increase mutual understanding and respect between the intercultural different countries. The existence of a multilateral coexistence program that has made the Brazilian migrant population continue to increase in the city of Hamamatsu, has encouraged the development of the Brazilian migrant community in the city.

The development of the industrial city of Hamamatsu, especially in the field of machinery and electronics, made more opportunities to work there. Not only industrial factories, but also an attractive factor is the availability of Brazilian special schools and Brazilian banks and restaurants in the city of Hamamatsu. The city of Hamamatsu has played an important role in the construction of cities for non-Japanese citizens, namely as a founding member of the Committee for Localities with a Concentrated Foreigner Population in 2001, establishing the Foreign Resident's Assembly, an assembly that opened a dialogue forum between the city government and foreign citizens, and The Hamamatsu Foundation for International Communications and Exchange (HICE) 
which functions as a bridge between the city government and foreigners in the city of Hamamatsu and provides language classes. In addition, the Hamamatsu Association on the International Exchange section has also played an important role, as well as other organizations such as The Chamber of Commerce and Industry and the Hamamatsu Junior Chamber of Commerce, which have handled issues regarding Nikkeijin.

One of the roles of HICE is to provide schools aimed not only at Japanese citizens, but also at foreigners in Hamamatsu. The center of the class is the Hamamatsu Foreign Resident Study Support Center. There is a Brazilian school located in the city of Hamamatsu, Japan, namely Mundo de Alegria which was founded in 2003. This school was built aiming to provide a place for children of Brazilian migrants who want to go to school so that it is not limited by Japanese culture because it has been devoted to Brazilian citizens whose children want to go to school. Not only schools, but the Hamamatsu Foundation for International Communications and Exchange (HICE) is a community that acts as a bridge between the city government and foreign citizens through the provision of services. Examples include Hamamatsu City, which provides all the information from how to live in Japan, counseling services, language classes, namely the Hamamatsu Foreign Resident Study Support Center, to information for daily life. In 2001, Hamamatsu City and 12 other local authorities formed a Local Authority Board with a Number of Foreigners (The Council of Local Authorities with a large of foreigners to facilitate horizontal knowledge and lobbying the central government for greater involvement (Komine, 2014).

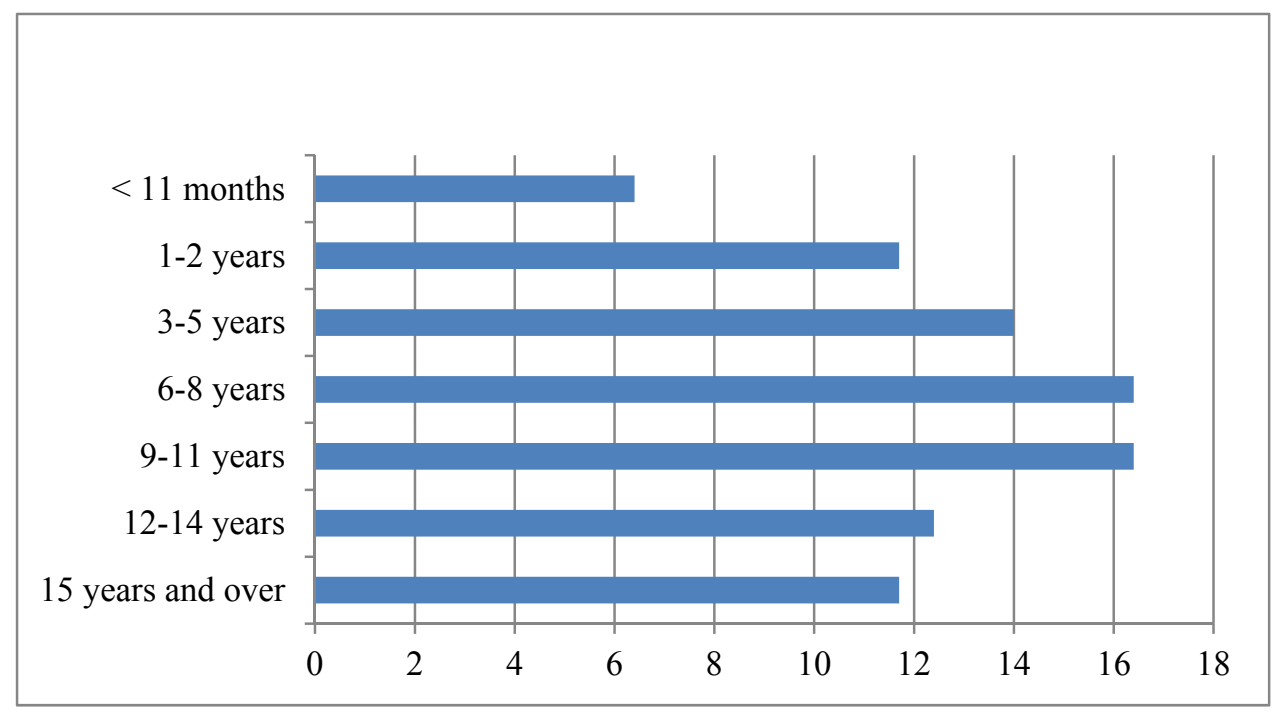

Figure 4. Brazilian living in Hamamatsu by length of stay

Source: Japan's Ministry of justice

In 2006, Hamamatsu City's international government affairs division surveyed around 1,200 South Americans (mainly Brazilian and Peruvian citizens) in the city (Yonekura \& Masana, 2015). People from Brazil tend to stay in Japan for longer periods in Japan than other native populations, and this trend is evident in the city of Hamamatsu as well. From the graph 5.3 above, shows a survey of Brazilian residents living in Japan precisely in the city of Hamamatsu in 2006, it can be seen that the length of stay of Brazilian respondents is between 6 to 8 years and for 9 to 11 years at $16.5 \%$.

In the case of Brazilians in Japan, the greater the community that grows in the area, the greater the shelter Brazilians has for living and working even with sufficient or no ability to master Japanese. From the data that has been described, it can be analyzed that with interpersonal relations between Nikkeijin who migrate to form a family and friendship network as evidenced by the continued increase in the Nikkeijin population in the city of Hamamatsu. The existence of this network which eventually produced a community such as the Hamamatsu Foundation for International Communications and Exchange (HICE). The existence of the HICE indicates an effort to coordinate fellow Brazilian migrants (Nikkeijin) in Japan to facilitate the exchange of information needed by fellow Brazilian migrants (Nikkeijin) in Japan. This shows the existence of kinship ties as fellow Brazilian migrants to form a social network. 
Aside from the formation of the community, the added value of Nikkeijin is that they tend to be cheap labor, they also help overcome labor shortages in Japan and there is no racial discrimination / homogeneity due to Brazilian migrants who still had Japanese blood in the past. These Nikkeijin will be more accepted by the Japanese people because they are still one ethnic group or said to be of one race, regardless of their nationality, allowing the Nikkeijin to accept customs and absorb Japanese work more easily than other foreigners. As time went on, the employment opportunities that Nikkeijin gained continued to increase and connect connections between fellow Brazilian migrants (Nikkeijin) closer to Japan. Based on its work, it has become more transparent, not only limited to unskilled jobs in industry, but also in the ethnic market, the influence on the growth of local Brazilian communities in Japan.

\subsection{Social Capital}

Social capital is a resource that is obtained by individuals or groups by having a network of introductions and acknowledgments with each other, both institutionalized and less institutionalized. Migrant networks can be perceived as a form of social capital formed to gain access to sources such as overseas employment, financial capital, high wages, the possibility to collect savings and send it. From this network, social capital provides access in the form of reduced costs and risks of implementing migration so as to encourage ongoing migration. At a certain point the number of migrants will form a network which will reduce the danger and cost of movement so that more people will migrate and result in the expansion of the network and so on. Migration behavior will also affect the area of origin over time.

\subsection{Declining Cost}

\subsubsection{Travel Expenses}

In addition to illegal foreign workers, there has been an increase in the number of Latin American workers of Japanese descent (Nikkeijin). The entry of Brazilian migrant workers was caused by immigration laws that had been revised in Japan in 1990. Where the initial principle of immigration laws owned by Japan was not allowed foreigners do unskilled work in Japan. However, after the revision of foreign citizens whose parents or grandparents were Japanese citizens to carry out any activities in Japan, including even unskilled jobs (Higuichi, 2006). Subsequently the migrants were allowed to stay in Japan for three years. The revision of immigration laws resulted in a dramatic increase in workers from Latin American countries, especially Brazil, which has long been the site of Japanese emigration. Because wage levels in Japan are much higher and Japanese society is much safer than Latin America, a number of Nikkeijin are interested in coming to Japan. The first and second generation of Nikkei immigrants, the numbers increased gradually as Japanese companies discovered Nikkeijin in Brazil as labor reserves, and Nikkei travel agents in Brazil (agenciasryoko-sha). Most Brazilian Nikkeijin workers use a recruitment agency for their first trip to Japan, which is usually sent not to producers, but to labor contractors and sent directly to factories in Japan.

The use of agents for outside labor migration is no exception to the Nikkeijin migration to Japan. Agencies are responsible for encouraging a rapid increase in the number of Brazilians in Japan. Most recruitment agents operate as travel agents, because they sell plane tickets to Japan. There are three types of agencies, namely pure travel agencies, recruitment agencies, and brokers. Purely established travel agency migration began again, they sold plane tickets to brokers. Recruitment agents, officially recognized as travel agents. Brokers are not registered as travel agents, they help provide employment opportunities in Japan and buy plane tickets from other agencies. The market-mediated migration system has developed well throughout Japanese society in Brazil (Nikkeijin).

Table 3. Sources of travel expenses to Japan

\begin{tabular}{|c|c|c|c|c|c|c|c|c|c|c|}
\hline & \multicolumn{2}{|c|}{$\begin{array}{l}\text { Loans from } \\
\text { Recruitment } \\
\text { Agencies }\end{array}$} & \multicolumn{2}{|c|}{$\begin{array}{l}\text { Personal } \\
\text { Savings }\end{array}$} & \multicolumn{2}{|c|}{$\begin{array}{l}\text { Loans from } \\
\text { Families }\end{array}$} & \multicolumn{2}{|l|}{ Other } & \multicolumn{2}{|c|}{ Total } \\
\hline & No. & $\%$ & No. & $\%$ & No. & $\%$ & No. & $\%$ & No. & $\%$ \\
\hline $\begin{array}{l}\text { Lower } \\
\text { Secondary }\end{array}$ & 404 & 69.0 & 111 & 18.5 & 35 & 5.8 & 40 & 6.7 & 600 & 100.0 \\
\hline Secondary & 499 & 65.8 & 162 & 21.4 & 39 & 5.1 & 58 & 7.7 & 758 & 100.0 \\
\hline Tertiary & 140 & 61.1 & 50 & 21.8 & 15 & 6.6 & 24 & 10.5 & 229 & 100.0 \\
\hline
\end{tabular}




\begin{tabular}{lllllllllll}
\hline $\begin{array}{l}\text { University } \\
\text { Student }\end{array}$ & 83 & 62.4 & 35 & 26.3 & 9 & 6.8 & 6 & 4.5 & 133 & 100.0 \\
\hline University & 142 & 56.3 & 74 & 29.4 & 13 & 5.2 & 23 & 9.1 & 252 & 100.0 \\
\hline None & 598 & 64.3 & 227 & 24.4 & 31 & 3.3 & 74 & 8.0 & 930 & 100.0 \\
\hline $\begin{array}{l}\text { Family } \\
\text { Unified }\end{array}$ & 210 & 68.4 & 56 & 18.2 & 19 & 6.2 & 22 & 7.2 & 307 & 100.0 \\
\hline $\begin{array}{l}\text { Migrated } \\
\text { Together }\end{array}$ & 304 & 77.0 & 60 & 15.2 & 14 & 3.5 & 17 & 4.3 & 395 & 100.0 \\
\hline $\begin{array}{l}\text { Unified } \\
\text { Family }\end{array}$ & 194 & 49.9 & 101 & 26.0 & 51 & 13.1 & 43 & 11.1 & 389 & 100.0 \\
\hline
\end{tabular}

The table above shows that two-thirds of respondents experienced their first trip to Japan using a loan from a recruitment agency. It can be concluded that the majority of Nikkeijin depend on recruitment, because they can find work and own homes there, and about $77 \%$ of migrant families use recruitment agencies more, to avoid the risk of not getting a job and housing before the employment.

Table 4. Registration of foreigners "permanent residents" by country of origin

\begin{tabular}{lllll}
\hline Country & 2003 & 2004 & 2005 & 2006 \\
\hline USA & 8,149 & 9,064 & 9,691 & 10,512 \\
\hline Brazil & 41,771 & 52,581 & 63,643 & 78,523 \\
\hline Philippines & 39,733 & 47,407 & 53,430 & 60,225 \\
\hline Korea & 39,807 & 42,960 & 45,184 & 47,679 \\
\hline Peru & 17,213 & 20,401 & 22,625 & 25,132 \\
\hline
\end{tabular}

Table 5. New arrivals of Brazilian nationals by status of residence

\begin{tabular}{lllll}
\hline Status of Residence & 2003 & 2004 & 2005 & 2006 \\
\hline Diplomat & 73 & 69 & 152 & 70 \\
\hline Official & 35 & 53 & 234 & 94 \\
\hline Professor & 10 & 9 & 4 & 5 \\
\hline Artist & 1 & 5 & 9 & 5 \\
\hline Religious & 40 & 36 & 29 & 33 \\
\hline Journalist & - & 2 & 2 & 2 \\
\hline Investor & 2 & 3 & - & 4 \\
\hline Researcher & 1 & 3 & 4 & 2 \\
\hline Engineer & 5 & 5 & 5 & 28 \\
\hline International service & 19 & 22 & 28 & 51 \\
\hline Intra-company transferee & 24 & 21 & 27 & 760 \\
\hline Entertainer & 938 & 741 & 820 & 33 \\
\hline Skilled labour & 15 & 19 & 29 & 15 \\
\hline Culture & 6 & 13 & 16 & 13,944 \\
\hline Temporary visitor & 7,749 & 9,527 & 12,737 & \\
\hline
\end{tabular}




\begin{tabular}{lllll}
\hline College student & 123 & 119 & 128 & 131 \\
\hline Trainee & 305 & 262 & 369 & 280 \\
\hline Dependent & 170 & 124 & 112 & 179 \\
\hline Designer & 9 & 23 & 20 & 12 \\
\hline $\begin{array}{l}\text { Spouse or child of Japanese } \\
\text { national }\end{array}$ & 9,902 & 8.893 & 8,299 & 6,745 \\
\hline
\end{tabular}

The two tables above are a description of citizens who are migrants in Japan, as well as a description of the list of jobs that were held by Nikkeijin in Japan in the period of 2003-2006. Table 5.4 shows that migrants originating from Brazil have a greater population in Japan than other countries entering Japan. Workers recruiters function as "translators", who provide the information and resources needed to work in Japan. This variant is referred to as a "market-mediated" migration system. From the data described above, it can be analyzed that the cost of migration has been reduced due to the development of a "market-mediated" migration system, which has further encouraged migration from Brazil to Japan.

\subsubsection{Living Cost}

The Brazilian Nikkeijin used to migrate out of Japan to get a more decent livelihood along with fears of logistical and financial support from the government to work in a large coffee plantation and at that time in dire need of workers (Kenneth, 2017). The Nikkeijin developed into the middle class with rapid urbanization and economic growth, but the hyperinflation that occurred in the 1980s encouraged them to find a stable livelihood and see an opportunity for Japan to experience a bubble economy but experienced a shortage of labor. work. This has also been facilitated by the existence of a labor supply network that helps access to get jobs in Japan for Brazilian Nikkeijin especially the second or third generation.

The migration industry is one of the main examples of intermediate structures, as a defense created and strengthened by the migration process itself (Haas, 2009). Examples are travel agents, lawyers, bankers, labor recruiters, interpreters, and traders as drivers in increasing migration. The occurrence of the migration process affects the ability of individuals and households with social relations to migrate. The existence of migration is also a challenge for the Japanese government. The existence of settlements and groups of migrants poses a location challenge facing the government, especially in the industrial area where Nikkeijin is employed as a factory worker. Until finally the government united to strengthen its politics (Light, 2013).

\subsubsection{Opportunity Cost}

Migrant networks tend to focus on reducing the direct costs of migration costs, information, and search as well as psychological opportunities and costs of migration. So that the migration network (migrant network) can be understood as a form of specific location on social capital that people take to get access to resources in other places (Haas, 2009). Massey conceptualizes migration as a diffusion process in society, where: The expanding network causes the cost of downward movement and the possibility of migration will continue to increase. This trend is mutually beneficial to one another, and over time migration spreads to cover all segments of society. The existence of this feedback occurs because the network was created by the act of migration itself. Once the number of connection networks in the area of origin reaches a critical level, migration will perpetuate itself because migration itself creates a social structure to support it (Massey 1990).

So besides (1) finance and (2) human capital, (3) social capital is the third important factor that determines a person's motivation and ability to migrate to another country. The change in the structure of demand for Brazilian workers can be seen in the development of a labor supply system that recruits more workers from Nikkeijin to Japanese factories. This can be seen from factories especially Hamamatsu, Shizuoka and Oizumi who provide contract work for Brazilian Nikkeijin because they are unable to attract their own Japanese residents to work in their factories (Kenneth, 2017). There is a preference to prioritize workers from Nikkeijin because it is in accordance with national interests which reduces companies employing illegal work and ethnic homogeneity and cultural continuity is upheld in Japanese society so that it is better able to accept jobs that have the same blood line with Japan according to Takeyuki Tsuda The number and Brazilian migrants (Nikkeijin) are an opportunity cost for those who have the opportunity to work in Japan not only unskilled jobs, but can grow and develop in larger Japanese industrial sectors. The increasing demand for Brazilian workers means that 
Brazilians will not move to Japan if they have not found work in industrial cities, such as working at the Suzuki factory in Hamamatsu city or the Sanyo factory in Oizumi city (Higuchi \& Kiyoto, 2003).

\subsection{Declining Risk}

\subsubsection{Policies on Reducing Migration Risk}

One way to reduce risk is to have a policy governing migration. Article 1 of the Immigration Control and Refugee Recognition Act stipulates that the purpose of regulating immigration is to provide fair control over the entry or exit of immigrants from Japan to all people and as a procedure in recognition of refugee status. Fair supervision of entry into or from Japan aims to achieve a reasonable balance between the smooth reception of foreign nationals and the unwanted removal of foreign nationals (Immigration Control, 2005). In achieving this goal, the Immigration Control Act regulates the status of the residence system, so that it can accept foreign nationals smoothly, for example, possessing advanced skills, as well as strictly handling foreign nationals who commit crimes in Japan.

The Alien Registration Law is aimed at foreign nationals living in Japan. Article 1 of the Law states its purpose as "To conduct charges against foreigners living in Japan by clarifying matters relating to their status and residence through the administration of citizen registration. the stranger. The Alien Registration Act is closely related to the Immigration Control Act, which is a provision on the examination of residence status, because both of them apply to foreign nationals residing in Japan. However, in many ways, the regulations on these two laws are quite different from one another.

\subsubsection{Strategies for Risk Diversification}

Risks from migratory lifestyles affect the education of migrant children. Children of ex-dekasseguiser tend to experience difficult language transitions when their families move between Brazil and Japan for a period of change. Many of those who returned to Brazil suffered from the limitations of bilingual languages, where difficulties were in Japanese and Portuguese. Thus creating great difficulties in their cultural adaptation, and making the Nikkeijin disadvantaged both at school and at work (Sasaki, 2008).

To overcome this problem, many Nikkei organizations offer support to both dekasseguisers and ex-dekasseguisers. Some of the main Nikkeijin organizations, including the Nikkeijin community, founded CIATE (Centro de Informacones e Apote ao Trabalhador no Exterior) - (Center of Information and Support for Workers Abroad), to provide legal advice, organize conferences, and promote publications on dekasseguiser. The Dekassegui Committee (Comissao de Estudos das Assuntos Relacinados ao Dekassegui) established in the community to discuss educational issues and facilitate the reading of dekasseguised children.

\section{Discussion}

Cross-border international population movements in recent years, especially developing countries to developed countries and between developing countries, have a significant impact on international relations. Relations between countries are often influenced by the actions of countries that carry out international migration where the effect is often increased in conflict, but in some conditions the outcome may be a pattern in developing cooperation between governments. In addition, international migration is influenced by regulations made by the state in relation to the entry and exit of migrants. The consequence is that regulations are influenced by relations between countries, because in determining what policies must be followed in relation to the international population movement, the state considers the actions of others. Economic setbacks in the regions of origin cause migrants to look for alternative solutions to survive.

This has finally encouraged the development of the spirit of globalization in the economies of various countries. On the one hand, the global capitalist system opens up broader employment opportunities without considering national identity, so that less skilled workers also enter the created market competition. After describing the data relating to social networks and social capital, the whole can be that Nikkeijin has two values, namely as a large group of relatively cheap labor with the advantage of working in the unskilled sector and can do what cannot be done by the Japanese population (kutsui, kinket). That way they can reduce the shortage of Japanese workers whose majority are residents of old age.

In addition, the existence of the Nikkeijin will not interfere with Japanese racial and social homogeneity, where the Japanese population does tend to be individual residents, it is difficult to accept outside influences. However, with Nikkeijin this will not be a problem because this Nikkeijin is a foreign resident who has mixed as a descendant of Japan. So that the Japanese population more accept the existence of Nikkeijin because it is considered as a "race" or arguably according to their race, because the Japanese population thinks that the 
Nikkeijin will quickly adapt, accept easily the conditions in Japan because there are still descendants from Japan so that it is expected to understand the conditions in Japan.

Some Nikkeijin have migrated to Japan with the aim of getting a chance to have a better life than in Brazil. The advantage of Nikkeijin migrating to Japan is the Japanese immigration law that allows anyone with Japanese parents or grandparents to apply for a long-term visa. It is proven that family relations and friendships are factors that can improve Nikkeijin in Japan. When one of the migrant families will start migrating, they will definitely bring one of their families to migrate and settle there. Even when they have settled in Japan, and have found work, they will invite other relatives who are still in Brazil to work in Japan

This can be seen from the formation of a community between migrants such as HICE and the Foreign Resident's Assembly which was formed because more and more foreign residents or migrants came to Japan and in this case the city of Hamamatsu. Many migrants who come to the city are migrants from Brazil who encourage the local government to conduct a program namely Hamamatsu Global City Vision in encouraging its citizens to uphold mutual multicultural values. Then, these Brazilian migrants also formed their own community, CIATE. CIATE itself has the aim to provide legal advice, as a gathering place, and obtain information needed for all migrants coming from Brazil. From this, it can be seen that the Brazilian Nikkeijin formed a network of interpersonal relationships that were realized into the community.

Existing kinship as a fellow Brazilian citizen who is of Japanese descent and returned to Japan to try his luck raises an interpersonal relationship between fellow migrants. The relationships formed make it easier to exchange information with others. And with the existence of interpersonal relationships in the end is getting bigger and institutionalizing until a community is formed which ultimately expands the network of interpersonal relationships. This has resulted in the formation of a social network. The Social Network was formed by the presence of Brazilian Nikkeijin working in Japan and then attracting other Brazilian Nikkeijin by increasing demand for Brazilian workers by several Japanese companies, especially for part-time workers compared to workers from other countries.

The social network formed in the form of the Brazilian Nikkeijin community will form social capital. This social capital can be seen and the existence of CIATE makes it easy for Brazilian migrants to get the information they need. In addition to collaborating with travel agencies in Brazil, it is able to reduce costs incurred to travel from Brazilian Nikkeijin to Japan, which is related to the increasing demand for Brazilian Nikkeijin workers in Japan. The established community also influences information needed by migrants, including information about work and housing.

This is also supported by the facilities needed by migrants from Brazil to carry out daily life in Japan such as language training centers such as the Hamamatsu Foreign Resident Study Support Center. In addition, with the establishment of a Brazilian school, Mundo de Alegria, so that access to education for migrant children is guaranteed. This reduces the costs required by a migrant to travel migrants. Risks associated with migration also reduce with the presence of community networks in destination countries so that they will get help when problems arise due to interpersonal relationships. In addition, there are policies that support the entry of the Brazilian Nikkeijin into Japan such as the ease provided by the Japanese government to work and settle in certain periods in the country and the economic conditions in Brazil that are less conducive so as to encourage them to look for a more decent life in other countries.

To that end, the increase in Brazilian migrants to Japan, especially the Brazilian Nikkeijin in the city due to the existence of a social network that is an interpersonal network that forms a CIATE like that then affects social capital where there are costs and risks incurred when migrating to Japan. The reduction in travel costs for migrating to Japan with the existence of a Brazilian travel agency with a job seeker's agency in Japan results in a reduction in the costs required to migrate. In addition, there is information that can be obtained from the Brazilian Nikkeijin community, thereby reducing the costs and risks of migrating. This is also supported by unfavorable economic conditions in Brazil and the presence of Brazilian Nikkeijin workers in Japan which is good enough to encourage them to migrate. From this, it can be seen that the formation of the Brazilian Nikkeijin migration network affects the ongoing migration that occurs from Brazil to Japan, especially in the city of Hamamatsu where there are several industries that need workers and put more emphasis on Nikkeijin workers and there are several Brazilian communities in the city that help each other fellow Nikkeijin Brazil both get information and in the need to interact with one another.

Policies that regulate immigrants and especially Brazilian migrants (Nikkeijin) benefit them especially Brazilian migrants (Nikkeijin) because those who migrate to Japan are generations of Japanese descent. The existence of institutions is also considered more important, because they are the ones who make the right choice of workers in 
certain categories. Cost reduction and risk reduction form social capital, which encourages Brazilian migrants (Nikkeijin) to migrate to Japan due to reduced costs, there is an opportunity cost where Brazilian workers get the opportunity to work in more important places such as in industrial factories.

\section{Conclusion}

Displacement of population to get a more decent life has been done in ancient times. As done by residents. Japan is going to another country or called Nikkeijin with one of the destinations being Brazil. In its development the Nikkeijin and his descendants traveled back to Japan to get a more decent living. This can be seen and an increase in the number of Brazilian migrants, especially those of Japanese descent. These Brazilian migrants are recorded to be the most in the industrial city of Hamamatsu, where many work are in line with the industrial development in the city. With the establishment of The Hamamatsu Foundation for International Communication and Exchange (HICE) is wrong one pointer is the increasing number of migrants in the city. For this reason, it is interesting for the role of the community in increasing Brazilian migrants in the city.

To see this phenomenon, Migrant Network Theory was used by Douglas Massey. This theory says that when a migration occurs, a network will be formed which can later facilitate the next migration. This can occur because of the social capital or intrapersonal relationships that they have which will reduce costs and from migration so as to encourage migration. Intrapersonal relationships that are meant are family relationships, kinship relationships, and friendships that will help one another.

In terms of social networks, there are several networks that help with the dissemination of information and help with migration. Like the Dekassegui Empreemdedor, Export Business was conducted to bring together migrants in the event until it was attended by President Lula. There is also the Brazilian Society of Japanese Culture or CIATE (Centro de Information e Aposo ao Trabalhardor no Exterior) where migrants gather to get information, support migrants, cause Legal Advice, hold meetings and publish information needed by the people near them. . In addition, the Dekassegui Committee which discussed the educational facilities for their children who were discriminated against in education in Japan. The policies issued such as Hamamatsu Global City Vision in 2001 that encourage support to establish a multicultural life. There is a Foreign Resident Assembly that voices the voice of migrant workers and HIC that facilitates relations between the city government and foreign citizens. And in terms of social capital, the existence of Japanese government policies such as the Immigration Control and Refugee Recognition of AJT and The Alben Registration AJT which provides enough convenience especially for migrants who are of Japanese descent and are no exception to the Dekasseguis or Brazilian Nikkeijin. There is also an increasing number of travel agents and travel agencies that are increasing so that the price of the trip will be reduced.

With the existence of several communities in Japan for Brazilian migrants as well as the existence of organizations, committees, or other forms that form a migration network formed to facilitate and fight for the needs of Brazilian migrants in the city of Hamamatsu. This is also supported by the reduction in costs and risks incurred when migrating from Brazil to Japan, especially for the Brazilian Nikkeijin where there are regulations and preferences that are accepted, especially for those looking for and finding work in Japan compared to other migrants and decreasing costs borne when migrating with the increasing number of employment bureaus and travel agents. For this reason, it can be seen that there has been an increase in Brazilian migrants in Japan, especially in the city of Hamamatsu due to the migration network that was formed such as the existence of various communities and other organizations that supported the existence of Intrapersonal relations which helped facilitate migration. This can be seen from an increase in the trend of Brazilian migrants who settled for a long time in the city in 2006. The migration network and Brazil reduced the risks of migrating as there was support for migrants in Hamamatsu where the HIC formed by the Hamamatsu Foreign Resident Study Support Center and the founding of a Brazilian school in 2003 making it easier for migrants especially for their children to get access to education.

\subsection{Implication for Further Research}

Based on the research conducted, the suggestion proposed by the author is the need for further research on the phenomenon of migration that occurs between Japan where there is an aging population, but the government and the Japanese people themselves limit the presence of foreign workers to enter the country. Or there is research comparing the phenomena that occur between migrants outside Nikkeijin and Nikkeijin migrants.

\section{References}

BBC News. (2007). Japan's Trial Run for Migrant Workers. Retrieved November 30, 2015, from http://news.bbe.co.uk/2/hi/bussiness/8025089.stm 
Brazil OECD. (2009). Retrieved March 30, 2015, from http://www.oecd.org/dev.americas/44535121.pdf

Calarans, E. (2009). Life as Decasseguis: The Brazzilian Community in Japan. Retrieved November 28, 2018, from http://www.hurights.or.jp/archives/focus/section2/2009/12/life-as-dekasseguis-the-brazzilian-community-in -japanhtm

Delfin, S. (2006). What Do Networks Do? The Role of Networks on Migration and "Coyote" Use. Georgetown University.

Goto, J. (2006). Latin Americans of the Japanese Origin (Nikkeijin): Working in Japan-A Survey. Kobe University: Japan. https://doi.org/10.1596/1813-9450-4203

Hamamatsu City. (2014, March). International Affairs Division. Retrieved from http://www.hamamatsu.shizioka.jp/.../iccvision en.pd

Hamamatsu City. (n.d.). Hamamatsu Intercultural City Vision. Retrieved from http://www.city.hamamatsu.shizuoka.jp/../iccvision-en.pd

Hamamatsu City. (n.d.). Retrieved from http://www.city.hamamatsu.shizuoka.jp/hamaeng/index.html

Hamamatsu Foreign Resident Study Support Center. (n.d.). Retrieved from http://www.hi-hice.jp/u-toc/en/picture.php

Has, H. D. (2009). Migration System Formation and Decline: A Theoretical Inquiry into the Self-perpetuating and Self-undermining dynamics of Migration Processes. University of Oxford.

Haug, S. (2008). Migration Networks and Migration Decisio-Making. Journal of Ethnic and Migration Studies, 34(4). https://doi.org/10.1080/13691830801961605

Higuchi, N. (2006). Brazilian Migration to Japan Trends, Modalities and Impact. Retrieved from http://www.um.org/esa/population/meetings/lttMigLAC/PI I_Higuchi.pdf

Higuchi, N., \& Tanno, K. (2013). What is Driving Brazil-Japan Migration? The Making and Remaking of the Brazilian Niche in Japan. International Journal of Japanese Sociology, 12(1), 33-47.

Imigration Control. (2005, November). Data Section. Immigration Bureau, Ministry of Justice, Japan.

Imigration Control. (2008). Data section. Retrieved from http://www.moj.go.jp/ENGLISH/index.html

Ishi, A. (n.d.). The Japanese-Brazilian Community in Japan and the "Brazilian diaspora" in the world. Musashi University.

Japan GDP. (2019). Retrieved from http://www.tradingeconomics.com/japan/gdp

Kashiwazaki, C. (2002). Japan's Resilient Demand for Roreign workers. Retrieved from http://www.migrationpolicy.org/article/japams-resilent-demand-foreign-workers

Kashiwazaki, C., \& Akaha, T. (2006). Japanese immigration policy: Responding to Conflicting Pressures. Retrieved December 3, 2018, from http://www.migrationpolicy.org/article/japanese-immigration-policy-responding-conflicting-pressures

King, R. (2012). Theories and typologies of Migration: An Overview and A Primer. Malmo Institute for Studies for Migration, Diversity and Welfare (MIM). Service Point Holmbers: Sweden.

Kingsberg, M. (2015). Repatriotation But Not "Return": A Japanese Brazilian Dekasegi Goes Back to Brazil. Retrieved November 30, 2018, from http://www.japanfocus.org/site/make_pdf/4304

Komine, A. (2014). When Migrans Became Denizens: Understandings Japan as a Reactive immigration Country.

Kurekova, L. (2011). Theories of Migration: Conceptual Review and Emprical Testing in the Context of the EU East-West Flows (p. 10). Central Europian University.

Lee, K. (n.d.). Alienating Ethnic Kin: Assessing Immigration Polices for the Brazilian Nikkeijin in Japan and Josejokok Marriage Miggrants in South Korea. Cornell.

Liang, Z., \& Chunyu, M. D. (2013). Migration within China from China to USA: The Effect of Migration Network, Selectivity, and Te Rular Political Economy in Fuju Privince. Popilation Studies, 67(2).

Light, I. (2013). The Migration Undustr in the United States, 1880-1924. Migration Studies, 1(3). 
Little Brazil. (n.d.). Hamamatsu and the Japan-Brazil Year of Exchange 2008. Retrieved from $\mathrm{http} / /$ www.city.hamamatsu.shizouka.jp/foreign/english/newsletter/no5.html

Massey, D. S. (1986). The social organization of Mexican Migrants to the United States. The ANNALS of the American Academy of Political and Social Science, 48(1).

Massey, D. S. (1994). The Social and Economic Origins of Immigration. The Social Contract. Bulletin Inter-American Parliamentary Group on Population and Development, NY.

Massey, D. S. Arango, J., Hugo, G., Kouaouci, A., Pellegrino, A., \& Taylor, J. E. (1993). Theories of International Migration: A Review and Apparaisal. Population and Development Review, 19(3), 431-466.

Ministry of Justice. (n.d.). Annual report of statistics on legal migrants.

Nakamura, A. (2008). Brazil Emigration Cenntenia in Japan: Japan, Brazil mark a century of settlement, family ties. $\quad$ Retrieved from http://www.japntimes.co.jp/news/2008/01/15/news/japan-brazil-mark-a-century-of-settlement-family-ties/\#. V10HeNIrLMx

Palloni, A., Massey, D. S., et al. (2001). Social Capital and International Migration: A Test using information on Family Networks. American Journal of Sociology, 106(5).

Partnership \& Business Development Division. (2007). Emerging Donors in International Development Assistance: The Brazil Case. Retrieved March 15, 2019, from http://www.idrc.ca/EN/Documents/case-of-brazil.pdf

Pratiwi, H. D. K. (2014). Immigration Control Policy as a Strategic Option Against the Phenomenon of Population Aging in Japan. Journal of Relationship Analysis, 3(3).

Roth, J. H. (2002). Brokered Homeland. Cornell University Press.

Sabina Stelzig, Brazil. (2018). Retrieved March 15, 2019, from http://www.bpb.de/gesellschaft/migration/laenderprofile/58243/brazil

Sakurai, C. (2008). Japanese-Brazilian: Past and Present. Retrieved from http://www.discovernikkei.org/en/journal/2008///24/copani-knt

Santos, D., \& Augusto, S. (2002). Historical Roots of the "Whitening" of Brazil. https://doi.org/10.1177/0094582X0202900104

Sasaki, K. (2008). Between Emigration and Immigration: Japanese Immigrants to Brazilan and their Descendants in Japan. Retrieved from http://www.camel.minpaku.ac.jp/dspace/bittream/10502/2045/1/SER77_005.pdf

Soetjipto, A., \& Trimayuni, P. (2013). Gender and International Relations: An Introduction. Yogyakarta: Jalasutra

Spittel, M. (1998). Testing Network Theory through an Analysis of Migration from Mexico to the United States.

Tsuda, T. (2008). Local citizenship and Foreign Workers in Japan. The Asia-Pacific Journal, 6(5).

Vogt, G. (2012). Historical Development of Migration. Retrieved March 17, 2016, from http://www.bpb.de/gesellschaft/migration/laenderprofile/150349/historical-development-of-migration

Yonekura, R., \& Tani, M. (2011). Broadcastingin a Multicultural Socienty: A Case Study in Hamamatsu. Retrieved from http://www.nhk.or.jp/bunken/english/report/pdf/11_no9_no8.pdf

\section{Copyrights}

Copyright for this article is retained by the author(s), with first publication rights granted to the journal.

This is an open-access article distributed under the terms and conditions of the Creative Commons Attribution license (http://creativecommons.org/licenses/by/4.0/). 